\title{
Oxidation of $\mathrm{Cr}$ (III)-Fe(III) Mixed-Phase Hydroxides by Chlorine: Implications on the Control of Hexavalent Chromium in Drinking Water
}

\author{
Michelle Chebeir and Haizhou Liu*๑ \\ Department of Chemical and Environmental Engineering, University of California at Riverside, Riverside, California 92521, United \\ States
}

Supporting Information

\begin{abstract}
The occurrence of chromium (Cr) as an inorganic contaminant in drinking water is widely reported. One source of $\mathrm{Cr}$ is its accumulation in ironcontaining corrosion scales of drinking water distribution systems as $\mathrm{Cr}$ (III)$\mathrm{Fe}(\mathrm{III})$ hydroxide, that is, $\mathrm{Fe}_{x} \mathrm{Cr}_{(1-x)}(\mathrm{OH})_{3(\mathrm{~s})}$, where $x$ represents the $\mathrm{Fe}(\mathrm{III})$ molar content and typically varies between 0.25 and 0.75 . This study investigated the kinetics of inadvertent hexavalent chromium $\mathrm{Cr}(\mathrm{VI})$ formation via the oxidation of $\mathrm{Fe}_{x} \mathrm{Cr}_{(1-x)}(\mathrm{OH})_{3(\mathrm{~s})}$ by chlorine as a residual disinfectant in drinking water, and examined the impacts of $\mathrm{Fe}$ (III) content and drinking water chemical parameters including $\mathrm{pH}$, bromide and bicarbonate on the rate of $\mathrm{Cr}(\mathrm{VI})$ formation. Data showed that an increase in $\mathrm{Fe}(\mathrm{III})$ molar content resulted in a significant decrease in the stoichiometric $\mathrm{Cr}(\mathrm{VI})$ yield and the rate of $\mathrm{Cr}(\mathrm{VI})$ formation, mainly due to chlorine decay induced by $\mathrm{Fe}$ (III) surface sites. An increase in bicarbonate enhanced the rate of $\mathrm{Cr}(\mathrm{VI})$ formation, likely due to the formation of Fe(III)-carbonato surface complexes that slowed down the scavenging reaction with chlorine. The presence of bromide significantly accelerated the oxidation of $\mathrm{Fe}_{x} \mathrm{Cr}_{(1-x)}(\mathrm{OH})_{3(\mathrm{~s})}$ by chlorine, resulting from the catalytic effect of bromide acting as an electron shuttle. A higher solution $\mathrm{pH}$ between 6 and 8.5 slowed down the oxidation of $\mathrm{Cr}$ (III) by chlorine. These findings suggested that the oxidative conversion of chromium-containing iron corrosion products in drinking water distribution systems can lead to the occurrence of $\mathrm{Cr}(\mathrm{VI})$ at the tap, and the abundance of iron, and a careful control of $\mathrm{pH}$, bicarbonate and bromide levels can assist the control of $\mathrm{Cr}(\mathrm{VI})$ formation.
\end{abstract}

\section{INTRODUCTION}

Chromium ( $\mathrm{Cr}$ ) can exist as hexavalent $\mathrm{Cr}(\mathrm{VI})$ and trivalent $\mathrm{Cr}(\mathrm{III})$ in drinking water. $\mathrm{Cr}(\mathrm{VI})$ is highly mobile and toxic, whereas $\mathrm{Cr}$ (III) forms minerals with low solubility at circumneutral $\mathrm{pH}$ and is also considered a micronutrient. ${ }^{1,2}$ The State of California set a new drinking water regulation specifically for $\mathrm{Cr}(\mathrm{VI})$ at $10 \mu \mathrm{g} / \mathrm{L}$ in $2014 .^{3}$ The U.S. EPA regulates total chromium in drinking water at $100 \mu \mathrm{g} / \mathrm{L}$, and a federal regulation solely for $\mathrm{Cr}(\mathrm{VI})$ may be established in the future. ${ }^{4}$ Traditional anthropogenic sources typically come from industrial waste discharge. ${ }^{5-7}$ In addition, natural occurrence of $\mathrm{Cr}(\mathrm{VI})$ originates from the natural weathering of $\mathrm{Cr}$ (III)-containing aquifer minerals in groundwater. ${ }^{8-10}$

In recent years, in situ generation of $\mathrm{Cr}(\mathrm{VI})$ in drinking water distribution systems from $\mathrm{Cr}$-containing corrosion scales has drawn an increasing attention. ${ }^{11,12}$ Corrosion products in drinking water pipes are found to contain up to $0.5 \%$ chromium by weight, far exceeding its natural abundance in the earth crust. ${ }^{13-15}$ In particular, considering that nearly $70 \%$ of pipes in water distribution systems in the U.S. are composed of iron materials (e.g., cast iron, ductile iron and cement-lined iron), chromium can accumulate extensively in iron corrosion scales over time. ${ }^{16-20}$ Chromium is typically present at trace levels below regulatory standards in treated drinking water, but over decades it can accumulate to very high levels in the corroded solids in distribution systems. In addition, iron piping materials are found to contain chromium impurities that serve as in situ sources. ${ }^{21-23}$ When coexisting with iron, $\mathrm{Cr}(\mathrm{III})$ forms mixed phases of $\mathrm{Cr}(\mathrm{III})-\mathrm{Fe}(\mathrm{III})$

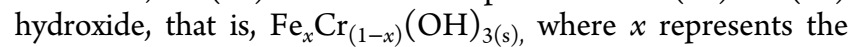
$\mathrm{Fe}$ (III) molar content and typically varies between 0.25 and $0.75 .^{24-26}$ In addition, $\mathrm{Fe}_{x} \mathrm{Cr}_{(1-x)}(\mathrm{OH})_{3(\mathrm{~s})}$ widely exists in iron-rich aquifer materials and its oxidation by $\mathrm{Mn}(\mathrm{IV})$ oxides contributes to the natural occurrence of $\mathrm{Cr}(\mathrm{VI})$ in groundwater. $^{27-29}$

The occurrence of $\mathrm{Cr}(\mathrm{VI})$ in drinking water distribution systems depends on a cascade of redox processes. In particular, the oxidation of $\mathrm{Cr}(\mathrm{III})$ solids by the residual disinfectant chlorine can take place in distribution systems, and results in the risk of an inadvertent generation of $\mathrm{Cr}(\mathrm{VI})$ at the tap. Nationwide surveys have indicated that the reaction pathways depended on $\mathrm{Cr}$ (III) speciation and its redox reactivity in distribution systems. ${ }^{11,17,30}$ Field sampling data from the third round of U.S. Environmental Protection Agency Unregulated Contaminant Monitoring Rule

Received: November 22, 2017

Revised: May 15, 2018

Accepted: May 17, 2018

Published: May 17, 2018 
Table 1. Characteristics of Synthesized Cr(III)-Fe(III) Hydroxide $\mathrm{Fe}_{x} \mathrm{Cr}_{(1-x)}(\mathrm{OH})_{3(\mathrm{~s})}$

$\begin{array}{lcccc}\begin{array}{c}\mathrm{Cr}(\mathrm{III})-\mathrm{Fe}(\mathrm{III}) \text { hydroxide } \\ \text { chemical formula }\end{array} & \begin{array}{c}\text { BET surface area } \\ \left(\mathrm{m}^{2} / \mathrm{g}\right)\end{array} & \mathrm{pH}_{\mathrm{pzc}} & \log K_{\mathrm{sp}}{ }^{a} & \begin{array}{c}E^{\mathrm{o}} \\ (\mathrm{V})^{b}\end{array} \\ \mathrm{Fe}_{0.25} \mathrm{Cr}_{0.75}(\mathrm{OH})_{3(\mathrm{~s})} \bullet 1.5 \mathrm{H}_{2} \mathrm{O} & 279 & 5.3 & -33.8 & 0.23 \\ \mathrm{Fe}_{0.5} \mathrm{Cr}_{0.5}(\mathrm{OH})_{3(\mathrm{~s})} \cdot \mathrm{H}_{2} \mathrm{O} & 355 & 3.8 & -34.5 & 0.38 \\ \mathrm{Fe}_{0.75} \mathrm{Cr}_{0.25}(\mathrm{OH})_{3(\mathrm{~s})} \cdot 1.5 \mathrm{H}_{2} \mathrm{O} & 198 & 5.5 & -34.7 & 0.82\end{array}$

${ }^{a}$ the value of $K_{\mathrm{sp}}$ is based on dissolution reactions listed in Text S1 in the SI. ${ }^{b} E^{\circ}$ is the standard half-reaction redox potential of the redox couple between $\mathrm{Fe}_{x} \mathrm{Cr}_{(1-x)}(\mathrm{OH})_{3(\mathrm{~s})}$ and $\mathrm{CrO}_{4}{ }^{2-}$.

(UCMR3) indicated that $\mathrm{Cr}(\mathrm{VI})$ levels increased from the entry to exit point of many distribution systems nationwide, and this trend correlated with the presence of chlorine as the residual disinfectant. ${ }^{11}$ Recent studies also showed that the oxidation of $\mathrm{Cr}$ (III) solids by chlorine can increase $\mathrm{Cr}(\mathrm{VI})$ levels in drinking water. ${ }^{12,31,32}$ In addition, mixed phases of $\mathrm{Cr}$ (III) oxides with other metals, for example, $\mathrm{Cu}_{2} \mathrm{Cr}_{2} \mathrm{O}_{5(\mathrm{~s})}$, exhibit a higher redox reactivity than pure phases of $\mathrm{Cr}(\mathrm{III}){ }^{12}$ Similarly, the coexistence of $\mathrm{Fe}(\mathrm{III})$ in $\mathrm{Fe}_{x} \mathrm{Cr}_{(1-x)}(\mathrm{OH})_{3(\mathrm{~s})}$ can possess unique reactivity with chlorine to generate $\mathrm{Cr}(\mathrm{VI})$, and the aging of $\mathrm{Cr}(\mathrm{III})$ solids can also impact its redox reactivity; however, there is little knowledge on the formation of $\mathrm{Cr}(\mathrm{VI})$ from $\mathrm{Fe}_{x} \mathrm{Cr}_{(1-x)}(\mathrm{OH})_{3(\mathrm{~s})}$ in drinking water.

Furthermore, the impacts of water chemical parameters including $\mathrm{pH}$, bromide and bicarbonate on the reactivity of $\mathrm{Cr}(\mathrm{III})-\mathrm{Fe}$ (III) hydroxide remain unknown. Bicarbonate and $\mathrm{pH}$ are important parameters to control corrosion in distribution systems. ${ }^{33,34}$ They impact complexation of metal surface carbonato and hydroxo species, and consequently surface redox reactivity of metal oxides. ${ }^{35} \mathrm{pH}$ can also impact the speciation of chlorine and its oxidative capacity. Bromide exhibits a catalytic effect on the chlorine-driven oxidation of transition metals. ${ }^{36}$ Recent studies show that bromide level in drinking water can increase by as much as 20 times in the future due to seawater intrusion, desalination, water reuse and brine discharge from alternative energy production (e.g., shale gas)..$^{37}$

Considering the importance of understanding the reactivity of $\mathrm{Fe}_{x} \mathrm{Cr}_{(1-x)}(\mathrm{OH})_{3(\mathrm{~s})}$ and consequently the development of effective $\mathrm{Cr}(\mathrm{VI})$ control strategies in water distribution infrastructure, the objectives of this study were to investigate the mechanisms of $\mathrm{Cr}(\mathrm{VI})$ formation via $\mathrm{Fe}_{x} \mathrm{Cr}_{(1-x)}(\mathrm{OH})_{3(\mathrm{~s})}$ oxidation by chlorine, and to quantify the impacts of $\mathrm{Fe}(\mathrm{III})$, bicarbonate, $\mathrm{pH}$ and bromide on the reaction kinetics and stoichiometry.

\section{MATERIALS AND METHODS}

All chemicals used in this study were reagent grade or higher. All solutions were prepared using deionized (DI) water (resistivity >18.2 M , Millipore System). Cr(III)-Fe(III) hydroxide solids with three different $\mathrm{Fe}$ (III) molar contents were synthesized using a standard protocol. ${ }^{38}$ In brief, solutions of $\mathrm{Fe}\left(\mathrm{NO}_{3}\right)_{3}$ and $\mathrm{CrCl}_{3}$ were mixed at a molar ratio of either $0.3: 1,1: 1$, or $3: 1$ at $\mathrm{pH} 7$ for 3 days. Ferrihydrite $\mathrm{Fe}(\mathrm{OH})_{3(\mathrm{~s})}$ was synthesized via the hydrolysis of $\mathrm{Fe}\left(\mathrm{NO}_{3}\right)_{3}$ at $\mathrm{pH} 7 .{ }^{39}$ All solids were washed with DI water three times and then centrifuged, frozen overnight and lyophilized for $24 \mathrm{~h}$. The freeze-dried solids were sequentially sieved through NO. 50, 170, and 325 mesh sieves. Sieved particles with nominal sizes between 45 and $90 \mu \mathrm{m}$ were collected and used in this study. Because of the amorphous
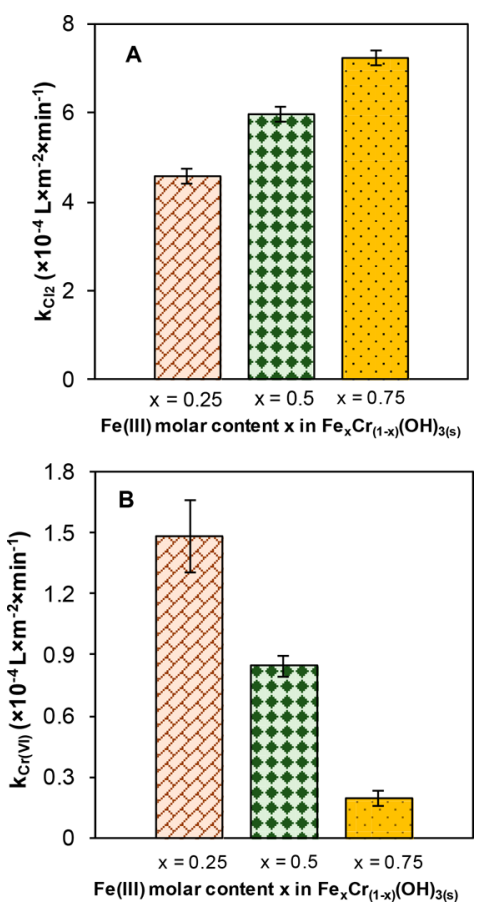

Figure 1. (A) Chlorine consumption and (B) $\mathrm{Cr}(\mathrm{VI})$ formation rate constants during the oxidation of iron chromite by chlorine. $[\mathrm{Cr}(\mathrm{III})]=2.8 \mathrm{mM},[\mathrm{HOCl}]=20 \mathrm{mg} \mathrm{Cl} / \mathrm{L},[\mathrm{Cr}(\mathrm{III})]:\left[\mathrm{Cl}_{2}\right]=$ 10:1, ionic strength $=10 \mathrm{mM}, \mathrm{pH} 7.0$.

nature of $\mathrm{Fe}_{x} \mathrm{Cr}_{(1-x)}(\mathrm{OH})_{3(s)}$ solids, X-ray diffraction (XRD) was not capable of characterizing their chemical compositions. To confirm the chemical compositions of synthesized solids, particles were acid digested, and $\mathrm{Cr}$ and $\mathrm{Fe}$ percentages were analyzed with an Agilent 7700 inductively coupled plasmamass spectrometry. The BET surface area of solids was measured using a Micromeritics ASAP 2020 surface area analyzer. Zeta potentials of $\mathrm{Fe}_{x} \mathrm{Cr}_{(1-x)}(\mathrm{OH})_{3(\mathrm{~s})}$ were measured by a Zeta Potential Analyzer (Brookhaven Instruments). The physicochemical parameters of the synthesized solids are listed in Table 1.

A $28 \mathrm{mM}$ free chlorine stock solution diluted from a $\mathrm{NaOCl}$ solution (Sigma-Aldrich) was freshly prepared every week. The concentration of chlorine was verified by titration with potassium permanganate. ${ }^{40}$ Before the start of an experiment, all solutions were purged with $\mathrm{N}_{2}$ gas to remove the dissolved $\mathrm{O}_{2}$. Following that, $0.28 \mathrm{mM}$ of chlorine (i.e., 20 $\mathrm{mg} \mathrm{Cl} / \mathrm{L}$ ) was quickly added into the reactor tube and mixed with $\mathrm{Fe}_{x} \mathrm{Cr}_{(1-x)}(\mathrm{OH})_{3(\mathrm{~s})}$. This chlorine concentration was higher than typical drinking water residual disinfectant concentration, but provided useful insight into reaction kinetics. The dosages of different $\mathrm{Cr}(\mathrm{III})-\mathrm{Fe}(\mathrm{III})$ hydroxide solids were controlled so that the $\mathrm{Cr}$ (III) molar concentration was constant at $2.8 \mathrm{mM}$, corresponding to a $\mathrm{Cr}$ (III)-tochlorine ratio of 10:1. In some experiments, ferrihydrite was used to examine the effect of Fe(III).

The solution $\mathrm{pH}$ was maintained at a targeted value $( \pm 0.2$ $\mathrm{pH}$ units) between 6.0 and 8.5 with $10 \mathrm{mM}$ phosphate buffer. Control experiments confirmed that the presence of phosphate buffer had a negligible impact on the reaction kinetics. Bromide level was varied between 0.1 and $1 \mathrm{mg} / \mathrm{L}$, and bicarbonate between 1 and $5 \mathrm{mM}$. In experiments with varying bicarbonate, $10 \mathrm{mM}$ MOPS (3-morpholinopropane-1sulfonic acid) was added as the $\mathrm{pH}$ buffer to avoid the 

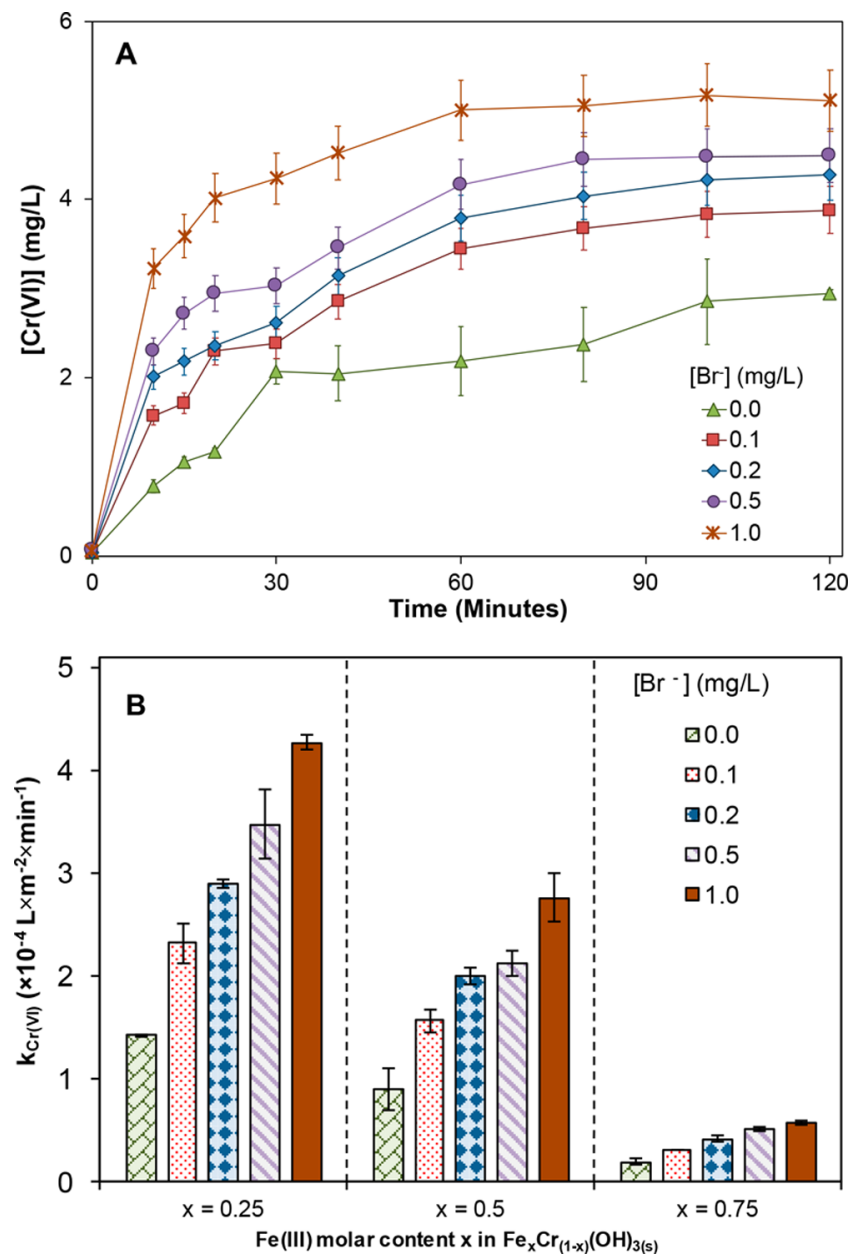

Figure 2. (A) Time profile for $\mathrm{Cr}(\mathrm{VI})$ generation from chlorine oxidation of $\mathrm{Fe}_{0.5} \mathrm{Cr}_{0.5}(\mathrm{OH})_{3(\mathrm{~s})}$. (B) Effect of bromide on the surface area normalized second-order $\mathrm{Cr}(\mathrm{VI})$ formation rate constants of $\mathrm{Cr}(\mathrm{III})-\mathrm{Fe}(\mathrm{III})$ hydroxide oxidation by chlorine. Initial $[\mathrm{Cr}(\mathrm{III})]=$ $2.8 \mathrm{mM},[\mathrm{HOCl}]=20 \mathrm{mg} \mathrm{Cl} / \mathrm{L}, \mathrm{Cr}(\mathrm{III}): \mathrm{Cl}_{2}=10: 1$, ionic strength $=10 \mathrm{mM}, \mathrm{pH} 7$.

potential interference of phosphate on $\mathrm{Fe}$ (III) surface complexation. $^{41,42}$ The solution ionic strength was kept at $10 \mathrm{mM}$ by adding a requisite amount of $\mathrm{NaClO}_{4}$. In some experiments, an excess of $1 \mathrm{mM}$ of benzoic acid (BA) was added as a chemical probe to assess the generation of reactive radical species during chlorine oxidation. All chlorine oxidation experiments were conducted in sealed glass tube reactors with no headspace or light exposure, and placed on a rotator to ensure continuous mixing. The ambient temperature was $20{ }^{\circ} \mathrm{C} \pm 2{ }^{\circ} \mathrm{C}$.

Sacrificial tubes were removed from the rotator at predetermined time intervals for chemical analyses. In some experiments, solutions were purged with $\mathrm{N}_{2}$ gas for $20 \mathrm{~min}$ to minimize the presence of dissolved $\mathrm{O}_{2}$, and the subsequent generation of dissolved $\mathrm{O}_{2}$ from the reaction was measured using a Mettler-Toledo probe. The leakage of $\mathrm{O}_{2}$ to the ambient environment was minimal. After that, concentrated $\mathrm{NaOH}$ was added to the suspension to release potentially adsorbed $\mathrm{Cr}(\mathrm{VI})$ from $\mathrm{Fe}_{x} \mathrm{Cr}_{(1-x)}(\mathrm{OH})_{3(s)}$, followed by filtration of the suspension through a $0.22 \mu \mathrm{m}$ Millipore PTFE filter. The concentration of $\mathrm{Cr}(\mathrm{VI})$ in the filtrate was measured using the diphenylcarbazide method. ${ }^{40}$ Chlorine concentration was measured using a modified DPD method,
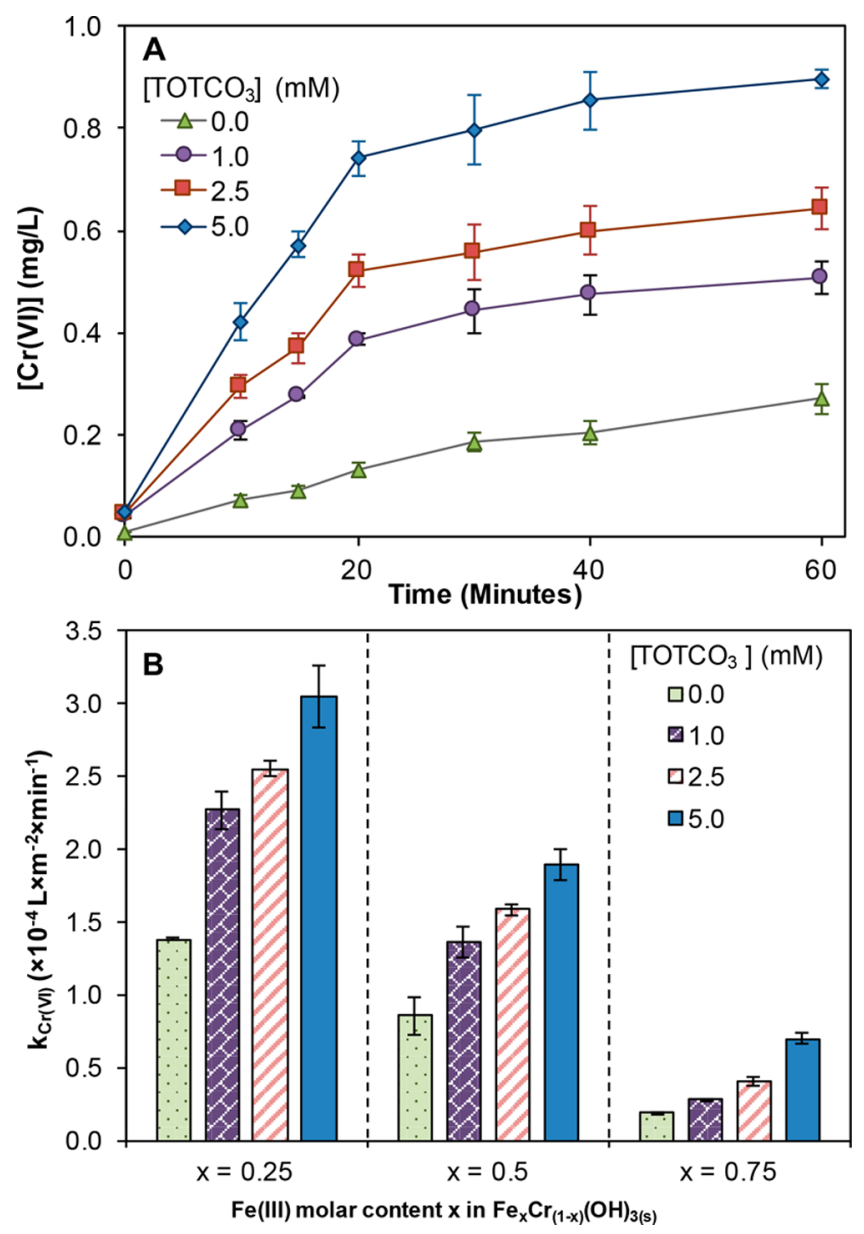

Figure 3. (A) Impact of carbonate concentration on chlorine consumption the oxidation of $\mathrm{Fe}_{0.75} \mathrm{Cr}_{0.25}(\mathrm{OH})_{3(\mathrm{~s})}$ by chlorine. (B) Effect of carbonate on the surface area normalized second-order $\mathrm{Cr}(\mathrm{VI})$ formation rate constants of $\mathrm{Cr}(\mathrm{III})-\mathrm{Fe}(\mathrm{III})$ hydroxide oxidation by chlorine. Initial $[\mathrm{Cr}(\mathrm{III})]=2.8 \mathrm{mM},[\mathrm{HOCl}]=20$ $\mathrm{mg} \mathrm{Cl}_{2} / \mathrm{L}, \mathrm{Cr}(\mathrm{III}): \mathrm{Cl}_{2}=10: 1$, ionic strength $=10 \mathrm{mM}, \mathrm{pH} 7$.

in which thioacetamide was added to eliminate any potential interference from $\mathrm{Cr}(\mathrm{VI}) .^{12}$ Data modeling using the Goal Seek function with Microsoft Excel was applied to obtain the reaction kinetics rate constants, and to correlate the relationship between the stoichiometric ratios of chlorine consumption and $\mathrm{Cr}(\mathrm{VI})$ formation rates.

\section{RESULTS AND DISCUSSION}

Kinetics of $\mathrm{Cr}(\mathrm{III})-\mathrm{Fe}(\mathrm{III})$ Hydroxide Oxidation by Chlorine and $\mathrm{Cr}(\mathrm{VI})$ Formation. The standard half-reaction redox potential of $\mathrm{Fe}_{x} \mathrm{Cr}_{(1-x)}(\mathrm{OH})_{3(s)}$ solids are calculated in Supporting Information (SI) Text S1. The values indicate that the oxidation of $\mathrm{Fe}_{x} \mathrm{Cr}_{(1-x)}(\mathrm{OH})_{3(\mathrm{~s})}$ by chlorine is thermodynamically feasible. To examine the reaction kinetics, a secondorder reaction kinetics model was introduced to quantify the rates of chlorine consumption and $\mathrm{Cr}(\mathrm{VI})$ formation:

$$
\begin{aligned}
& \frac{\mathrm{d}\left[\mathrm{Cl}_{2}\right]}{\mathrm{d} t}=-k_{\mathrm{Cl}_{2}}\left[\mathrm{Cr}(\mathrm{III})_{s}\right]\left[\mathrm{Cl}_{2}\right]\left(S_{\mathrm{Cr}(\mathrm{III})_{(s)}}\right) \\
& \frac{\mathrm{d}[\mathrm{Cr}(\mathrm{VI})]}{\mathrm{d} t}=k_{\mathrm{Cr}(\mathrm{VI})}\left[\mathrm{Cr}(\mathrm{III})_{s}\right]\left[\mathrm{Cl}_{2}\right]\left(S_{\mathrm{Cr}(\mathrm{III})_{(s)}}\right)
\end{aligned}
$$

$k_{\mathrm{Cl} 2}$ and $k_{\mathrm{Cr}(\mathrm{VI})}$ are the surface-area normalized rate constants for chlorine consumption and $\mathrm{Cr}(\mathrm{VI})$ formation, respectively 


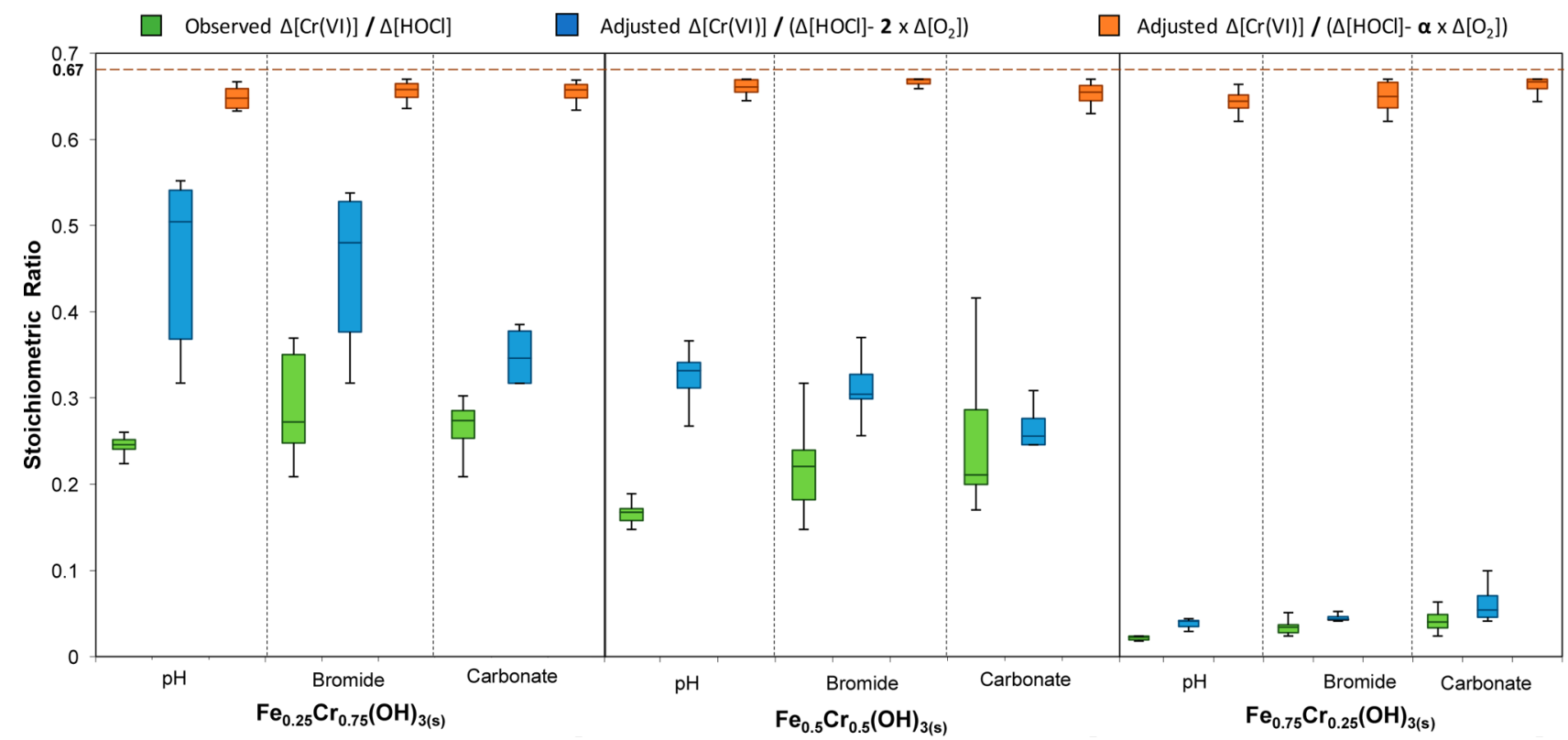

Figure 4. Average stoichiometric ratio for varying water quality parameters and different $\mathrm{Cr}(\mathrm{III})-\mathrm{Fe}(\mathrm{III})$ hydroxides. The green box plots represent the stoichiometric ratio based on $\Delta \mathrm{Cr}(\mathrm{VI}) / \Delta \mathrm{HOCl}$. The blue box plots represent the stoichiometric ratio based on $\Delta \mathrm{Cr}(\mathrm{VI}) /(\Delta \mathrm{HOCl}$ $\left.-2 \Delta \mathrm{O}_{2}\right)$. The orange box plots represent the stoichiometric ratio based on $\Delta \mathrm{Cr}(\mathrm{VI}) /\left(\Delta \mathrm{HOCl}-\alpha \Delta \mathrm{O}_{2}\right)$. The whiskers of the box plot represent the 10th and 90th percentiles of concentration. The lower quartile, middle and upper quartile represent the 25th, 50th, and 75th percentile values.

$\left(\mathrm{L} \cdot \mathrm{m}^{-2} \cdot \mathrm{min}^{-1}\right) \cdot\left[\mathrm{Cl}_{2}\right]$ is the free chlorine concentration $(\mathrm{mol} /$ $\mathrm{L}),\left[\mathrm{Cr}(\mathrm{III})_{(s)}\right]$ is the concentration of $\mathrm{Cr}(\mathrm{III})$ in $\mathrm{Cr}(\mathrm{III})-$ $\mathrm{Fe}$ (III) hydroxide $(\mathrm{g} / \mathrm{L})$, and $S_{\mathrm{Cr}(\mathrm{III})(\mathrm{s})}$ is the BET surface area of $\mathrm{Cr}(\mathrm{III})-\mathrm{Fe}$ (III) hydroxide $\left(\mathrm{m}^{2} / \mathrm{g}\right)$. The model-fitted data correlated well with the experimental data, with a minimal $R^{2}$ ranging between 0.85 and 0.95 for every set of experiment.

Surface-area normalized rate constants of chlorine consumption with $\mathrm{Cr}(\mathrm{III})-\mathrm{Fe}(\mathrm{III})$ hydroxide increased with $\mathrm{Fe}(\mathrm{III})$ molar contents, that is, the value of $x$ in $\mathrm{Fe}_{x} \mathrm{Cr}_{(1-x)}(\mathrm{OH})_{3(\mathrm{~s})}$ (Figure 1A). These $k_{\mathrm{Cl} 2}$ values were 2-3 times higher than the rate constants observed with pure phases of $\mathrm{Cr}$ (III) oxides that do not contain $\mathrm{Fe}(\mathrm{III})$, for example, $\mathrm{Cr}(\mathrm{OH})_{3(\mathrm{~s})}$ and $\mathrm{Cr}_{2} \mathrm{O}_{3(\mathrm{~s})}{ }^{12}$ Meanwhile, the rate constant of $\mathrm{Cr}(\mathrm{VI})$ formation decreased significantly with increasing $\mathrm{Fe}(\mathrm{III})$ content: from $1.5 \times 10^{-4}$ to $1.9 \times 10^{-5} \mathrm{~L}$. $\mathrm{m}^{-2} \cdot \mathrm{min}^{-1}$ when the value of $x$ in $\mathrm{Fe}_{x} \mathrm{Cr}_{(1-x)}(\mathrm{OH})_{3(\mathrm{~s})}$ increased from 0.25 to 0.75 (Figure $1 \mathrm{~B}$ ). This trend suggested that the presence of $\mathrm{Fe}(\mathrm{III})$ in $\mathrm{Cr}$ (III)-containing solids preferentially promoted the reaction kinetics of chlorine consumption but diminishing $\mathrm{Cr}(\mathrm{VI})$ formation.

Bromide. The presence of bromide enhanced the reaction kinetics. As the bromide concentration increased from 0 to 1 $\mathrm{mg} / \mathrm{L}$, an enhanced $\mathrm{Cr}(\mathrm{VI})$ formation was observed (Figure $2 \mathrm{~A})$, and the rate constant of $k_{\mathrm{Cr}(\mathrm{VI})}$ increased by approximately 3 times (Figure 2B). Meanwhile, chlorine consumption kinetics accelerated (SI Figure S1A) and the rate constant approximately doubled (SI Figure S1B). The promotive effects of bromide on the oxidation reaction resulted from an electron shuttle mechanism. Bromide readily reacted with $\mathrm{HOCl}$ to generate hypobromous acid $(\mathrm{HOBr}){ }^{43}$ Prior studies demonstrated that $\mathrm{HOBr}$ is more electrophilic than $\mathrm{HOCl}$ and consequently exhibited a faster kinetics in oxidizing electron-rich compounds including transition metals and organics. ${ }^{36,44,45}$ Control experiments with $\mathrm{HOBr}$ also showed that $\mathrm{HOBr}$ oxidized $\mathrm{Fe}_{x} \mathrm{Cr}_{(1-x)}(\mathrm{OH})_{3(\mathrm{~s})}$ much faster than $\mathrm{HOCl}$ did (SI Figure S2). Therefore, in a bromide- containing system, $\mathrm{HOBr}$ becomes the primary oxidant as bromide essentially acts as an electron shuttle that drives the oxidation of $\mathrm{Cr}(\mathrm{III})-\mathrm{Fe}(\mathrm{III})$ hydroxide to $\mathrm{Cr}(\mathrm{VI})$ by chlorine:

$$
\mathrm{Fe}_{x} \mathrm{Cr}_{(1-x)}(\mathrm{OH})_{3(s)}+\mathrm{HOCl} \stackrel{-}{\hdashline \mathrm{Br}^{-} \cdots} \mathrm{CrO}_{4}^{2-}+\mathrm{Fe}^{3+}+\mathrm{H}^{+}+\mathrm{Cl}^{-}
$$

Bicarbonate. Bicarbonate exhibited a moderate impact on the reaction kinetics. With increasing total bicarbonate concentration $\left(\mathrm{TOTCO}_{3}\right)$ from 0 to $5 \mathrm{mM}$ at $\mathrm{pH} 7$, the rate constant of $\mathrm{Cr}(\mathrm{VI})$ formation increased by approximately $200 \%$ (Figure 3A), and $\mathrm{Fe}_{x} \mathrm{Cr}_{(1-x)}(\mathrm{OH})_{3(\mathrm{~s})}$ with a lower $\mathrm{Fe}(\mathrm{III})$ molar content exhibited a higher sensitivity to the impact of bicarbonate on the rate of $\mathrm{Cr}(\mathrm{VI})$ formation (Figure 3B). Meanwhile, the rate of chlorine consumption increased by an average of $75 \%$ with the same amount of bicarbonate increase (SI Figure S3).

The impact of bicarbonate on the reaction kinetics is likely due to the formation of $\mathrm{Fe}(\mathrm{III})$-carbonato complexes, which has been known to decrease the redox reactivity of $\mathrm{Fe}$ (III) surface sites. ${ }^{35}$ In contrast, bicarbonate had a negligible effect on the redox reactivity of $\mathrm{Cr}$ (III) surface sites, as demonstrated by the negligible effect of bicarbonate on the oxidation of a pure phase of $\mathrm{Cr}(\mathrm{III})$ solid, that is, $\mathrm{Cr}(\mathrm{OH})_{3(\mathrm{~s})}$ by chlorine (SI Figure S4). Therefore, the presence of bicarbonate suppressed the reactivity of $\mathrm{Fe}(\mathrm{III})$ surface sites on $\mathrm{Fe}_{x} \mathrm{Cr}_{(1-x)}(\mathrm{OH})_{3(\mathrm{~s})}$ with respect to chlorine, and increased the availability of $\mathrm{Cr}(\mathrm{III})$ surface site subject to chlorine oxidation. As a result, the presence of bicarbonate enhanced the rate of $\mathrm{Cr}(\mathrm{VI})$ formation via $\mathrm{Fe}_{x} \mathrm{Cr}_{(1-x)}(\mathrm{OH})_{3(\mathrm{~s})}$ oxidation. $p H$. The reaction kinetics were observed to decrease with increasing $\mathrm{pH}$. The rate of chlorine consumption decreased by an average of $40 \%$ with $\mathrm{pH}$ rising from 6.0 to 8.5 . For example, the chlorine consumption rate constant of $\mathrm{Fe}_{0.75} \mathrm{Cr}_{0.25}(\mathrm{OH})_{3(\mathrm{~s})}$ declined from $9.2 \times 10^{-4}$ to $5.3 \times 10^{-4}$ $\mathrm{L} \cdot \mathrm{m}^{-2} \cdot \mathrm{min}^{-1}$ when $\mathrm{pH}$ increased from 6.0 to 8.5 (SI Figure S5A). The $\operatorname{Cr}(\mathrm{VI})$ formation rate constant from 


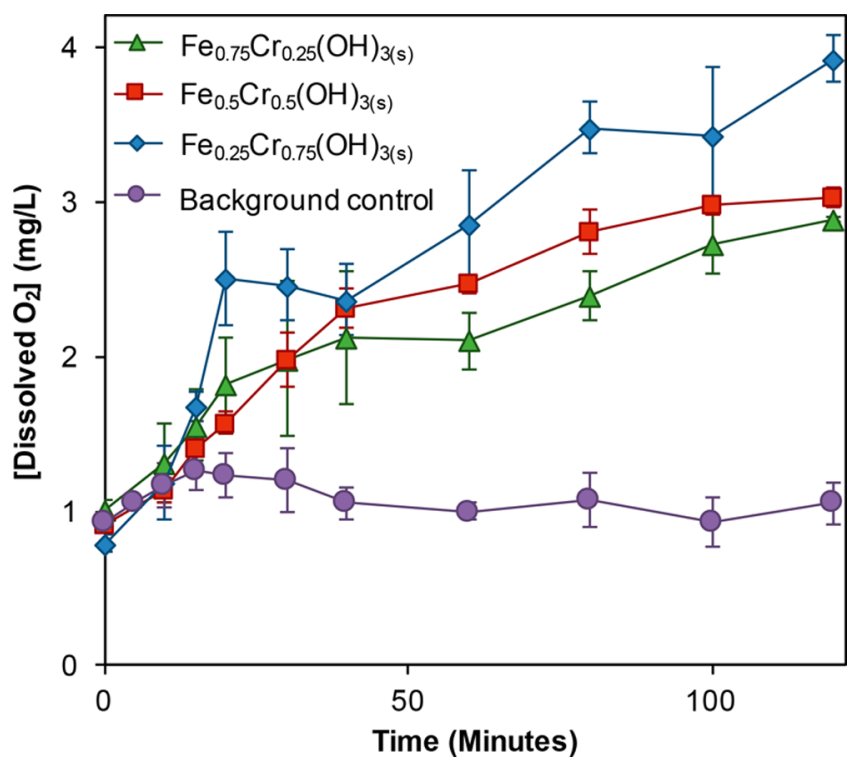

Figure 5. Oxygen generation over the course of the reaction. Initial $[\mathrm{Cr}(\mathrm{III})]=2.8 \mathrm{mM},[\mathrm{HOCl}]=20 \mathrm{mg} \mathrm{Cl} / 2, \mathrm{Cr}(\mathrm{III}): \mathrm{Cl}_{2}=10: 1$, ionic strength $=10 \mathrm{mM}, \mathrm{pH}$ 7. Oxygen data in the background control represents the average background oxygen levels from control experiments that include only chlorine or $\mathrm{Fe}_{x} \mathrm{Cr}_{(1-x)}(\mathrm{OH})_{3(\mathrm{~s})}$.

$\mathrm{Fe}_{0.25} \mathrm{Cr}_{0.75}(\mathrm{OH})_{3(\mathrm{~s})}$ decreased from $2.4 \times 10^{-5}$ to $8.0 \times 10^{-6}$ $\mathrm{L} \cdot \mathrm{m}^{-2} \cdot \mathrm{min}^{-1}$ when $\mathrm{pH}$ increased from 6.0 to 8.5 (SI Figure $\mathrm{S} 5 \mathrm{~B})$. The $\mathrm{pH}$ effect was likely associated with metal hydroxo complexation on the surface of $\mathrm{Fe}_{x} \mathrm{Cr}_{(1-x)}(\mathrm{OH})_{3(\mathrm{~s})}$. For example, the solution $\mathrm{pH}$ affects $\mathrm{Cr}$ (III)-hydroxo surface complexation. ${ }^{46,47}$ Measurement of zeta potential showed that the surface of $\mathrm{Fe}_{x} \mathrm{Cr}_{(1-x)}(\mathrm{OH})_{3(\mathrm{~s})}$ became more negatively charged with increasing $\mathrm{pH}$ (SI Figure S6), suggesting that $\mathrm{Cr}(\mathrm{III})$ surface complexes with a higher extent of hydroxylation predominated at higher $\mathrm{pHs}$ and they had a lower redox reactivity with chlorine. In addition, at higher $\mathrm{pHs,}$ especially above its $\mathrm{pK}$ value at 7.6 , chlorine speciation favors the deprotonated form of $\mathrm{OCl}^{-}$. The protonated $\mathrm{HOCl}$ is a more facile oxidant than the deprotonated $\mathrm{OCl}^{-48}$ therefore, an increase in $\mathrm{pH}$ from 6 to 8.5 also converts chlorine to a less effective oxidant and contributes to the slow-down of $\mathrm{Fe}_{x} \mathrm{Cr}_{(1-x)}(\mathrm{OH})_{3(\mathrm{~s})}$ oxidation.

Reaction Stoichiometry and $\mathrm{Cr}(\mathrm{VI})$ Formation Mechanisms. The theoretical stoichiometry of the reaction, defined as the molar ratio of $\mathrm{Cr}(\mathrm{VI})$ generated to chlorine consumed, that is, $\Delta[\mathrm{Cr}(\mathrm{VI})] / \Delta[\mathrm{HOCl}]$, is 0.67 based on the number of electron transfer in the redox reaction. Experimental data with $\mathrm{Fe}_{x} \mathrm{Cr}_{(1-x)}(\mathrm{OH})_{3(\mathrm{~s})}$ showed that the observed stoichiometry of $\Delta \mathrm{Cr}(\mathrm{VI}) / \Delta \mathrm{HOCl}$ was between 0.02 and 0.24 for all three $\mathrm{Fe}_{x} \mathrm{Cr}_{(1-x)}(\mathrm{OH})_{3(s)}$ solids under different chemical conditions (green-color box plots in Figure 4). The under-stoichiometric formation of $\mathrm{Cr}(\mathrm{VI})$ was likely associated with additional reaction pathways. First, the oxidation of $\mathrm{Cr}(\mathrm{III})$ can generate $\mathrm{Cr}(\mathrm{V})$ oxide intermediates. ${ }^{12}$ Autodecomposition of $\mathrm{Cr}(\mathrm{V})$ intermediates reproduces $\mathrm{Cr}(\mathrm{III})$ and dissolved $\mathrm{O}_{2}$, resulting in one molecule of $\mathrm{O}_{2}$ generation for every two molecules of chlorine consumption. Indeed, a significant amount of dissolved $\mathrm{O}_{2}$ formation was observed during the oxidation of $\mathrm{Cr}$ (III)-Fe(III) hydroxide (Figure 5). To take this reaction pathway into consideration, an adjusted stoichiometric ratio was calculated as $\Delta[\mathrm{Cr}(\mathrm{VI})] /\left(\Delta[\mathrm{HOCl}]-2 \times \Delta\left[\mathrm{O}_{2}\right]\right)$. The adjusted stoichiometry increased significantly, but still fell
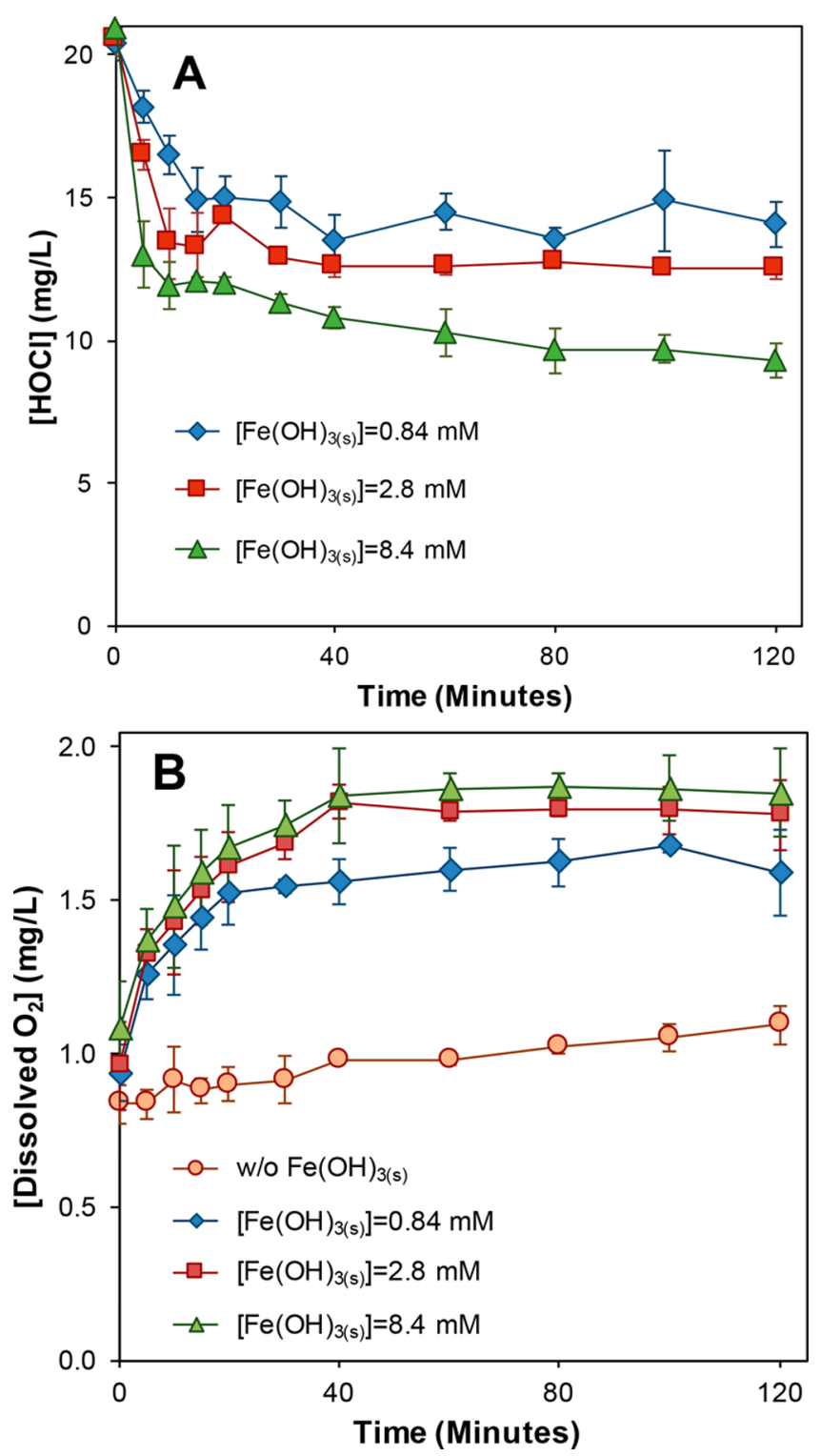

Figure 6. (A) Chlorine decrease in the presence of ferrihydrite. (B) Oxygen generation in the presence of ferrihydrite. Average background oxygen is $1 \mathrm{mg} / \mathrm{L}$. Initial $[\mathrm{HOCl}]=20 \mathrm{mg} \mathrm{Cl} / \mathrm{L}$, ionic strength $=10 \mathrm{mM}, \mathrm{pH} 7.0$.

below the theoretical value of 0.67 (blue-color box plots in Figure 4). Second, as the $\mathrm{x}$ value in $\mathrm{Fe}_{x} \mathrm{Cr}_{(1-x)}(\mathrm{OH})_{3(\mathrm{~s})}$ increased from 0.25 to 0.75 , the stoichiometry of $\Delta[\mathrm{Cr}-$ $(\mathrm{VI})] / \Delta[\mathrm{HOCl}]$ decreased significantly (green- and bluecolor box plots in Figure 4), accompanied by a $36 \%$ increase in oxygen generation (Figure 5). This suggested an additional reaction pathway specific to the presence of $\mathrm{Fe}(\mathrm{III})$ in $\mathrm{Fe}_{x} \mathrm{Cr}_{(1-x)}(\mathrm{OH})_{3(\mathrm{~s})}$ that consumed chlorine without $\mathrm{Cr}(\mathrm{VI})$ generation.

To further investigate the reaction mechanism involving $\mathrm{Fe}(\mathrm{III})$ surface sites, additional control experiments were conducted in the presence of a pure phase of $\mathrm{Fe}$ (III) solid, that is, ferrihydrite $\mathrm{Fe}(\mathrm{OH})_{3(\mathrm{~s})}$. Data showed that the chlorine decay was accelerated with the introduction of ferrihydrite (Figure 6A), and was accompanied by the generation of dissolved $\mathrm{O}_{2}$ (Figure $6 \mathrm{~B}$ ). The nonlinear increase of $\mathrm{O}_{2}$ production with $\mathrm{Fe}(\mathrm{OH})_{3(\mathrm{~s})}$ dosage is likely due to the limitation on the available $\mathrm{Fe}(\mathrm{III})$ reactive surface sites, e.g., 


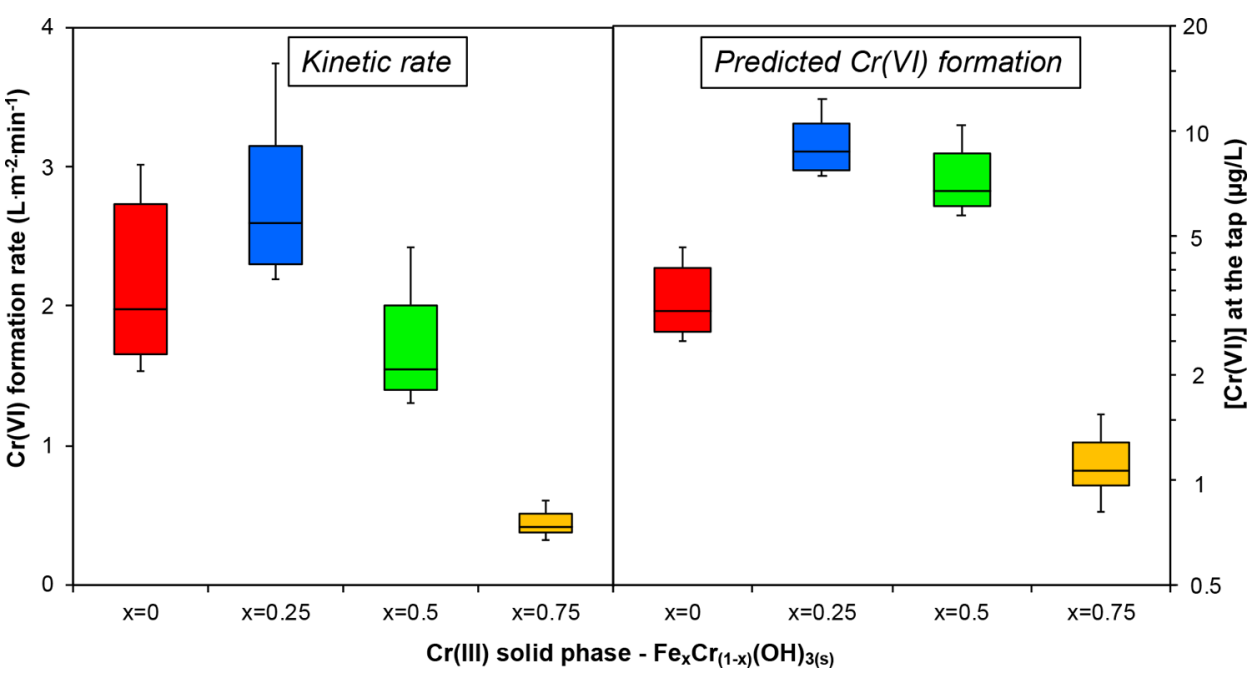

Figure 7. Box-plot of predicted $\mathrm{Cr}(\mathrm{VI})$ formation rate constants and the enhanced $\mathrm{Cr}(\mathrm{VI})$ formation in drinking-water distribution systems. The solid line in each box is the median value; the lower and upper box edges are the 25th and 75th percentiles, respectively. Whisker bars represent the 5th and 95th percentiles. The percentile distributions are predicted on the basis of $\mathrm{Cr}(\mathrm{VI})$ formation rate constants obtained from this study and statistical distributions of bromide concentration in U.S. source waters. The data with pure phase $\operatorname{Cr}(\mathrm{III})$ solids where $x=0$ was obtained from a prior study. ${ }^{12}$ The kinetics model simulation on enhanced $\mathrm{Cr}(\mathrm{VI})$ formation is based on a water distribution system with $0.3 \mathrm{mg} / \mathrm{L}$ chlorine residual, $100 \mu \mathrm{g} / \mathrm{L}$ residual $\mathrm{Cr}(\mathrm{III})$ solids, and a residence time of 2 days.

aggregation of ferrihydrite particles during the course of the reaction. A correlation between oxygen generation and chlorine decay in the presence of ferrihydrite exhibited a stoichiometric ratio of 0.1 (SI Figure S7), suggesting that the decay of chlorine was enhanced by $\mathrm{Fe}$ (III) surface sites with $\mathrm{Fe}_{x} \mathrm{Cr}_{(1-x)}(\mathrm{OH})_{3(s)}$. Similar halogen oxidant decay (e.g., $\mathrm{HOCl}$ and $\mathrm{ClO}_{2}$ ) enhanced by transition metal oxides has been previously observed. ${ }^{49-51}$

Accordingly, the reaction stoichiometry of $\Delta \mathrm{Cr}(\mathrm{VI}) /$ $\Delta \mathrm{HOCl}$ during $\mathrm{Fe}_{x} \mathrm{Cr}_{(1-x)}(\mathrm{OH})_{3(\mathrm{~s})}$ oxidation by chlorine was further adjusted to consider the pathway of $\mathrm{Fe}(\mathrm{III})$-induced chlorine decay and $\mathrm{O}_{2}$ generation. An oxygen coefficient $\alpha$ was introduced to quantify the contribution of reactions that decomposed chlorine to generate $\mathrm{O}_{2}$ while not converting $\mathrm{Cr}(\mathrm{III})$ to $\mathrm{Cr}(\mathrm{VI})$ in $\mathrm{Fe}_{x} \mathrm{Cr}_{(1-x)}(\mathrm{OH})_{3(\mathrm{~s})}$. The value of $\alpha$ represented the extent of chlorine scavenging reactions without generating $\mathrm{Cr}(\mathrm{VI})$, i.e., two reaction pathways that generate $\mathrm{O}_{2}: \mathrm{Cr}(\mathrm{V})$ intermediate formation and $\mathrm{Fe}(\mathrm{III})$ induced chlorine decay. When all reaction mechanisms were considered, the adjusted stoichiometry of $\Delta[\mathrm{Cr}(\mathrm{VI})] /$ $\left(\Delta \mathrm{HOCl}-\alpha \times \Delta \mathrm{O}_{2}\right)$ approached the expected value of 0.67 (orange-color box plots in Figure 4).

Overall, the value of $\alpha$ ranged between 2 and 7, but increased with the number of $\mathrm{x}$ in $\mathrm{Fe}_{x} \mathrm{Cr}_{(1-x)}(\mathrm{OH})_{3(\mathrm{~s})}$ (SI Figure S8). A larger $\alpha$ coefficient indicates a stronger inhibitive effect on $\mathrm{Cr}(\mathrm{VI})$ formation via $\mathrm{Fe}_{x} \mathrm{Cr}_{(1-x)}(\mathrm{OH})_{3(\mathrm{~s})}$ oxidation by chlorine. The positive correlation between $\alpha$ and $x$ represents an increasing importance of the $\mathrm{Fe}(\mathrm{III})$-induced chlorine decay pathway as the $\mathrm{Fe}$ (III) molar fraction increases in $\mathrm{Fe}_{x} \mathrm{Cr}_{(1-x)}(\mathrm{OH})_{3(\mathrm{~s})}$.

As chlorine is decayed into dissolved $\mathrm{O}_{2}$ and chloride by $\mathrm{Fe}(\mathrm{III})$ surface sites on $\mathrm{Fe}_{x} \mathrm{Cr}_{(1-x)}(\mathrm{OH})_{3(\mathrm{~s})}$, it can also involve the generation of short-lived intermediate radicals including hydroxyl radical $\left(\mathrm{HO}^{\bullet}\right)$, chlorine atom $\left(\mathrm{Cl}^{\bullet}\right)$ and chlorine dimer $\mathrm{Cl}_{2}{ }^{\bullet-}$ prior to the formation of chloride and $\mathrm{O}_{2}{ }^{52,53}$ Possible reactions were discussed in SI Text S2. To further evaluate the generation of reactive radical species, experiments were conducted with the addition of excess benzoic acid (BA) as a scavenger for all reactive radicals. BA reacts quickly with $\mathrm{HO}^{\bullet}, \mathrm{Cl}^{\bullet}$ and $\mathrm{Cl}_{2}{ }^{\bullet-}$, but does not react with chlorine or interfere with chlorine decay in the presence of $\mathrm{Fe}(\mathrm{III})$ and Cr(III) solids (SI Figure S9). Results showed that in the presence of $\mathrm{BA}$, the formation of $\mathrm{O}_{2}$ via chlorine decay by $\mathrm{Fe}(\mathrm{OH})_{3(\mathrm{~s})}$ was completely inhibited (SI Figure S10A). The amount of $\mathrm{O}_{2}$ generation via chlorine decay by $\mathrm{Fe}_{x} \mathrm{Cr}_{(1-x)}(\mathrm{OH})_{3(\mathrm{~s})}$ also decreased by approximately $40 \%$ in the presence of BA (SI Figure S10B). This observation suggests that about $40 \%$ of oxygen formation was contributed by $\mathrm{Fe}(\mathrm{III})$ sites on $\mathrm{Fe}_{x} \mathrm{Cr}_{(1-x)}(\mathrm{OH})_{3(\mathrm{~s})}$ that involves the formation of reactive radical species, with the remaining $60 \%$ contributed by $\mathrm{Cr}(\mathrm{III})$ sites via the $\mathrm{Cr}(\mathrm{V})$ intermediate formation/decay.

Environmental Implications. Drinking water distribution systems are reactive and lined with corrosion scales that are in situ sources of trace metal contaminants including chromium. In iron-containing distribution systems, accumulated $\mathrm{Cr}$ (III) in corrosion scales was reactive with residual chlorine, but the existence of $\mathrm{Fe}(\mathrm{III})$ in corrosion scales can greatly diminish $\mathrm{Cr}(\mathrm{VI})$ formation. For example, based on the $\mathrm{Cr}(\mathrm{VI})$ formation rate constants obtained from this study at different levels of $\mathrm{pH}$, bicarbonate and bromide, as well as the statistical distribution of bromide concentrations in U.S. source waters, ${ }^{54}$ a kinetics model was established (SI Text S3). The model predicts that the 50th percentile $\mathrm{Cr}(\mathrm{VI})$ concentration in tap water can increase substantially between 1 and $9 \mu \mathrm{g} / \mathrm{L}$, and a higher molar fraction of $\mathrm{Fe}(\mathrm{III})$ in the $\mathrm{Fe}_{x} \mathrm{Cr}_{(1-x)}(\mathrm{OH})_{3(\mathrm{~s})}$ solid phase generally leads to a lower $\mathrm{Cr}(\mathrm{VI})$ formation potential (Figure 7).

To control $\mathrm{Cr}(\mathrm{VI})$ level at the tap, especially for aging drinking water distribution infrastructure composed of corroded iron piping materials and free chlorine as the residual disinfectant, effective water management strategies include $\mathrm{pH}$ adjustment and bicarbonate control as posttreatment steps prior to entrance to drinking water distribution systems, and the prevention of halide input in source water, for example, seawater intrusion or point source 
discharge from energy sector. A mobilization or resuspension of $\mathrm{Cr}$ (III)-containing iron oxide will increase the risk of in situ $\mathrm{Cr}(\mathrm{III})$ conversion to $\mathrm{Cr}(\mathrm{VI})$ in drinking water distribution system. Considering that a majority of drinking water distribution infrastructure is based on iron material dominant pipe system, a better control of the redox reactivity of ironcontaining $\mathrm{Cr}$ (III) solids is important to develop future water management strategies.

\section{ASSOCIATED CONTENT}

\section{S Supporting Information}

The Supporting Information is available free of charge on the ACS Publications website at DOI: 10.1021/acs.est.7b06013.

Additional descriptions on figures of zeta potential of $\mathrm{Cr}(\mathrm{III})-\mathrm{Fe}(\mathrm{III})$ hydroxides, $\mathrm{Cr}$ (III) solid oxidation kinetics and standard redox potential calculations (PDF)

\section{AUTHOR INFORMATION}

\section{Corresponding Author}

*Phone (951) 827-2076; fax (951) 827-5696; e-mail: haizhou@engr.ucr.edu.

\section{ORCID}

Haizhou Liu: 0000-0003-4194-2566

\section{Notes}

The authors declare no competing financial interest.

\section{ACKNOWLEDGMENTS}

This research was supported by grants to H.L. from the U.S. National Science Foundation CAREER Program (CBET1653931), and to M.C. from the National Science Foundation Graduate Research Fellowship and IGERT Water Sense Fellowship. We thank our group members John Orta and Handong Wang at UC Riverside for assistance in this project.

\section{REFERENCES}

(1) Vincent, J. The Nutritional Biochemistry of Chromium(III); Elsevier, 2011.

(2) Nriagu, J. O.; Nieboer, E. Chromium in the Natural and Human Environments; John Wiley \& Sons, 1988.

(3) California Environmental Protection Agency; State Water Resources Board. Hexavalent Chromium in Drinking Water. http://www.waterboards.ca.gov/drinking_water/certlic/ drinkingwater/Chromium6.shtml.

(4) United States Environmental Protection Agency. Unregulated Contaminant Monitoring Rule 3 (UCMR 3).http://water.epa.gov/ lawsregs/rulesregs/sdwa/ucmr/ucmr3/index.cfm.

(5) Loock-Hattingh, M. M.; Beukes, J. P.; van Zyl, P. G.; Tiedt, L. R. $\mathrm{Cr}(\mathrm{VI})$ and conductivity as indicators of surface water pollution from ferrochrome production in South Africa: four case studies. Metall. Mater. Trans. B 2015, 46, 2315-2325.

(6) du Preez, S. P.; Beukes, J. P.; van Zyl, P. G. Cr(VI) generation during flaring of CO-Rich off-gas from closed ferrochromium submerged arc furnaces. Metall. Mater. Trans. B 2015, 46, 10021010.

(7) Kotaś, J.; Stasicka, Z. Chromium occurrence in the environment and methods of its speciation. Environ. Pollut. 2000, 107 (3), 263283.

(8) Jardine, P. M.; Mehlhorn, T. L.; Bailey, W. B.; Brooks, S. C.; Fendorf, S.; Gentry, R. W.; Phelps, T. J.; Saiers, J. E. Geochemical processes governing the fate and transport of chromium(III) and chromium (VI) in soils. Vadose Zone J. 2011, 10, 1058-1070.
(9) Oze, C.; Bird, D. K.; Fendorf, S. Genesis of hexavalent chromium from natural sources in soil and groundwater. Proc. Natl. Acad. Sci. U. S. A. 2007, 104, 6544-6549.

(10) Gonzalez, A. R.; Ndung'u, K.; Flegal, A. R. Natural occurrence of hexavalent chromium in the Aromas Red Sands Aquifer, California. Environ. Sci. Technol. 2005, 39, 5505-5511.

(11) Chebeir, M.; Chen, G.; Liu, H. Emerging investigators series: frontier review: occurrence and speciation of chromium in drinking water distribution systems. Environ. Sci.: Water Res. Technol. 2016, 2 (6), 906-914.

(12) Chebeir, M.; Liu, H. Kinetics and mechanisms of $\mathrm{Cr}(\mathrm{VI})$ formation via the oxidation of $\mathrm{Cr}(\mathrm{III})$ solid phases by chlorine in drinking water. Environ. Sci. Technol. 2016, 50 (2), 701-710.

(13) Peng, C.-Y.; Korshin, G. V.; Valentine, R. L.; Hill, A. S.; Friedman, M. J.; Reiber, S. H. Characterization of elemental and structural composition of corrosion scales and deposits formed in drinking water distribution systems. Water Res. 2010, 44 (15), 45704580.

(14) Peng, C.-Y.; Korshin, G. V. Speciation of trace inorganic contaminants in corrosion scales and deposits formed in drinking water distribution systems. Water Res. 2011, 45 (17), 5553-5563.

(15) Peng, C.-Y.; Ferguson, J. F.; Korshin, G. V. Effects of chloride, sulfate and natural organic matter (NOM) on the accumulation and release of trace-level inorganic contaminants from corroding iron. Water Res. 2013, 47 (14), 5257-5269.

(16) Friedman, M. Metals Accumulation and Release within the Distribution System: Evaluation and Mitigation; Park City Municipal Corporation (Utah); Water Research Foundation: Denver, CO, 2016.

(17) Frey, M.; Seidel, C.; Edwards, M. Occurrence Survey of Boron and Hexavalent Chromium; American Water Works Association: Denver, CO, 2005.

(18) Liu, J.; Chen, H.; Yao, L.; Wei, Z.; Lou, L.; Shan, Y.; Endalkachew, S.; Mallikarjuna, N.; Hu, B.; Zhou, X. The spatial distribution of pollutants in pipe-scale of large-diameter pipelines in a drinking water distribution system. J. Hazard. Mater. 2016, 317, 2735.

(19) Cui, Y.; Liu, S.; Smith, K.; Yu, K.; Hu, H.; Jiang, W.; Li, Y. Characterization of corrosion scale formed on stainless steel delivery pipe for reclaimed water treatment. Water Res. 2016, 88, 816-825.

(20) Hill, A. S.; Friedman, M. J.; Reiber, S. H.; Korshin, G. V.; Valentine, R. L. Behavior of trace inorganic contaminants in drinking water distribution systems. J. - Am. Water Works Assoc. 2010, 102 (7), 107-118.

(21) Melendres, C. A.; Pankuch, M.; Li, Y. S.; Knight, R. L. Surface enhanced Raman spectroelectrochemical studies of the corrosion films on iron and chromium in aqueous solution environments. Electrochim. Acta 1992, 37 (15), 2747-2754.

(22) Guo, Q. Increase of lead and chromium in drinking water from using cement-motar-lined pipes: initial modeling and assessment. J. Hazard. Mater. 1997, 56, 181-213.

(23) Gonzalez, S.; Lopez-Roldan, R.; Cortina, J. Presence of metals in drinking water distribution networks due to pipe material leaching: a review. Toxicol. Environ. Chem. 2013, 95 (6), 870-889.

(24) Papassiopi, N.; Vaxevanidou, K.; Christou, C.; Karagianni, E.; Antipas, G. S. E. Synthesis, characterization and stability of $\mathrm{Cr}(\mathrm{III})$ and $\mathrm{Fe}(\mathrm{III})$ hydroxides. J. Hazard. Mater. 2014, 264, 490-497.

(25) Eary, L. E.; Rai, D. Kinetics of chromate reduction by ferrous iron. Environ. Sci. Technol. 1996, 30 (5), 1614-1617.

(26) Dai, C.; Zuo, X.; Cao, B.; Hu, Y. Homogeneous and heterogeneous $\left(\mathrm{Fe}_{\mathrm{x}} \mathrm{Cr}_{1-\mathrm{x}}\right)(\mathrm{OH})_{3}$ precipitation: implications for $\mathrm{Cr}$ sequestration. Environ. Sci. Technol. 2016, 50 (4), 1741-1749.

(27) Pan, C.; Catalano, J. G.; Qian, A.; Giammar, D. E. Rates of $\mathrm{Cr}(\mathrm{VI})$ generation from $\mathrm{Cr}_{\mathrm{x}} \mathrm{Fe}_{1-\mathrm{x}}(\mathrm{OH})_{3}$ solids upon reaction with manganese oxide. Environ. Sci. Technol. 2017, 51 (21), 12416-12423.

(28) Oze, C.; Bird, D. K.; Fendorf, S. Genesis of hexavalent chromium from natural sources in soil and groundwater. Proc. Natl. Acad. Sci. U. S. A. 2007, 104 (16), 6544-6549. 
(29) Hausladen, D. M.; Fendorf, S. Hexavalent chromium generation within naturally structured soils and sediments. Environ. Sci. Technol. 2017, 51 (4), 2058-2067.

(30) McNeill, L.; McLean, J.; Edwards, M.; Parks, J. State of the science of hexavalent chromium in drinking water; Water Res. Found., 2012.

(31) Lindsay, D. R.; Farley, K. J.; Carbonaro, R. F. Oxidation of $\mathrm{Cr}^{\mathrm{III}}$ to $\mathrm{Cr}^{\mathrm{VI}}$ during chlorination of drinking water. J. Environ. Monit. 2012, 14 (7), 1789.

(32) Lai, H.; McNeill, L. S. Chromium redox chemistry in drinking water systems. J. Environ. Eng. 2006, 132 (8), 842-851.

(33) Schock, M. R.; Wagner, I.; Oliphant, R. J. Internal Corrosion of Water Distribution Systems; American Water Works Association: Denver, CO, 1996.

(34) Liu, H.; Schonberger, K. D.; Korshin, G. V.; Ferguson, J. F.; Meyerhofer, P.; Desormeaux, E.; Luckenbach, H. Effects of blending of desalinated water with treated surface drinking water on copper and lead release. Water Res. 2010, 44 (14), 4057-4066.

(35) Li, W.; Orozco, R.; Camargos, N.; Liu, H. Mechanisms on the impacts of alkalinity, $\mathrm{pH}$, and chloride on persulfate-based groundwater remediation. Environ. Sci. Technol. 2017, 51 (7), 3948-3959.

(36) Allard, S.; Fouche, L.; Dick, J.; Heitz, A.; von Gunten, U. Oxidation of manganese(II) during chlorination: role of bromide. Environ. Sci. Technol. 2013, 47 (15), 8716-8723.

(37) Good, K. D.; VanBriesen, J. M. Power plant bromide discharges and downstream drinking water systems in Pennsylvania. Environ. Sci. Technol. 2017, 51 (20), 11829-11838.

(38) Hansel, C. M.; Wielinga, B. W.; Fendorf, S. Structural and compositional evolution of $\mathrm{Cr} / \mathrm{Fe}$ solids after indirect chromate reduction by dissimilatory iron-reducing bacteria. Geochim. Cosmochim. Acta 2003, 67 (3), 401-412.

(39) Jambor, J. L.; Dutrizac, J. E. Occurrence and Constitution of natural and synthetic ferrihydrite, a widespread iron oxyhydroxide. Chem. Rev. 1998, 98 (7), 2549-2586.

(40) Rice, E. W.; Bridgewater, L. Standard Methods for the Examination of Water and Wastewater; American Public Health Association: Washington, D.C., 2012.

(41) Génin, J.-M. R.; Dhouibi, L.; Refait, P.; Abdelmoula, M.; Triki, E. Influence of phosphate on corrosion products of iron in chloridepolluted-concrete-simulating solutions: ferrihydrite vs green rust. Corrosion 2002, 58 (6), 467-478.

(42) Benali, O.; Abdelmoula, M.; Refait, P.; Génin, J.-M. R. Effect of orthophosphate on the oxidation products of $\mathrm{Fe}(\mathrm{II})-\mathrm{Fe}(\mathrm{III})$ hydroxycarbonate: the transformation of green rust to ferrihydrite. Geochim. Cosmochim. Acta 2001, 65 (11), 1715-1726.

(43) Kumar, K.; Margerum, D. W. Kinetics and mechanism of general acid-assisted oxidation of bromide by hypochlorite and hypochlorous acid. Inorg. Chem. 1987, 26 (16), 2706-2711.

(44) Westerhoff, P.; Chao, P.; Mash, H. Reactivity of natural organic matter with aqueous chlorine and bromine. Water Res. 2004, 38 (6), 1502-1513.

(45) Echigo, S.; Minear, R. A. Kinetics of the reaction of hypobromous acid and organic matters in water treatment processes. Water Sci. Technol. 2006, 53 (11), 235-243.

(46) Richard, F. C.; Bourg, A. C. M. Aqueous geochemistry of chromium: A review. Water Res. 1991, 25 (7), 807-816.

(47) Gómez, V.; Callao, M. P. Chromium determination and speciation since 2000. TrAC, Trends Anal. Chem. 2006, 25 (10), $1006-1015$

(48) Benjamin, M. M.; Lawler, D. F. Water Quality Engineering: Physical/Chemical Treatment Processes. Chapter 10: Redox Processes and Disinfection; John Wiley \& Sons, Inc.: Hoboken, NJ, 2013.

(49) Liu, C.; von Gunten, U.; Croué, J.-P. Enhanced chlorine dioxide Decay decay in the presence of metal Oxides: Relevance to drinking water distribution systems. Environ. Sci. Technol. 2013, 47 (15), 8365-8372.

(50) Lister, M. W. Decomposition of sodium hypochlorite: the catalyzed reaction. Can. J. Chem. 1956, 34 (4), 479-488.
(51) Sandin, S.; Karlsson, R. K. B.; Cornell, A. Catalyzed and uncatalyzed decomposition of hypochlorite in dilute solutions. Ind Eng. Chem. Res. 1956, 34 (4), 479-488; Ind. Eng. Chem. Res. 2015, 54 (15), 3767-3774.

(52) Kornweitz, H.; Burg, A.; Meyerstein, D. Plausible mechanisms of the Fenton-like reactions, $\mathrm{M}=\mathrm{Fe}(\mathrm{II})$ and $\mathrm{Co}(\mathrm{II})$, in the presence of $\mathrm{RCO} 2(-)$ substrates: are $\mathrm{OH}(\bullet)$ radicals formed in the process? J. Phys. Chem. A 2015, 119 (18), 4200-4206.

(53) Heckert, E. G.; Seal, S.; Self, W. T. Fenton-like reaction catalyzed by the rare earth inner transition metal cerium. Environ. Sci. Technol. 2008, 42 (13), 5014-5019.

(54) Wilson, J. M.; Wang, Y.; VanBriesen, J. M. Sources of high total dissolved solids to drinking water supply in Southwestern Pennsylvania. J. Environ. Eng. 2013, 140, B4014003. 